\title{
Arsenic retention on technosols prepared with nanoparticles for treatment of mine drainage water
}

\author{
D. Bolaños ${ }^{1}$, V. Sánchez ${ }^{1}$, J. Paz ${ }^{2}$, M. Balseiro ${ }^{3}$ \& L. Cumbal ${ }^{2,4}$ \\ ${ }^{1}$ Department of Earth and Construction Science, Universidad de las Fuerzas Armadas ESPE, Sangolqui, Ecuador \\ ${ }^{2}$ Department of Life Science and Agriculture, Universidad de las Fuerzas Armadas ESPE, Sangolquí, Ecuador \\ ${ }^{3}$ Department of Chemical Engineering, Centre for Research in Environmental Technologies (CRETUS), \\ Universidade de Santiago de Compostela, Spain \\ ${ }^{4}$ Center of Nanoscience and Nanotechnology (CENCINAT), Universidad de las Fuerzas Armadas ESPE, \\ Sangolquí, Ecuador
}

\begin{abstract}
Arsenic (As) concentrations of 4.8 to $27.5 \mu \mathrm{g} \mathrm{L}^{-1}$ have been detected in wastewater of gold mines in southern Ecuador (Portovelo) thus there is a need of applying remediation techniques to avoid superficial and groundwater contamination. In this study we have prepared a technosol composed by a ferric soil collected in the mining area and multicomponent nanoparticles synthetized using sodium borohydride and orange peel extract as co-reductants. The sorption capacity of the technosol was experimentally characterized using sorption isotherms. Langmuir model fits the experimental results and its parameters such as maximum sorption capacity and adsorption bond energy are $71185 \mathrm{mg} \mathrm{kg}^{-1} 7.50 \mathrm{~kg} \mathrm{mg}^{-1}$, respectively. Based on these preliminary results, it seems that the as-prepared technosol will be a cheap cost solution for capturing arsenic from the mine drainage water.
\end{abstract}

\section{INTRODUCTION}

Mine drainage water usually contains high concentrations of heavy metals and other compounds. Due to poor handling, this contaminated water may leach and migrate to ground and spring water, becoming a potential contaminant of drinking water sources (Bolaños, 2015; Polizzotto et al., 2006). There are many available technologies to cleanup As-contaminated water, whose efficiency and applicability will mainly depend on the chemical form of As in water (Cumbal, 2004). Adsorption of As in specific sorbents has been widely used due to its high versatility, easy operation and handling, and low costs. The application of specifically "tailored" technosols, composed of soil components and non-harmful residues with sorption capacities for specific contaminants, has shown successful results on the restoration of degraded mining areas contaminated with a wide variety of trace metals and metalloids (Macías, 2012). On the other hand, nanosorbents has emerged as a promising alternative for the cleanup of As-contaminated water (zero valent iron and iron oxide nanoparticles), because of their distinctive and advantageous properties, such as the small size, high surface area, and high reactivity due to the large number of sorption active sites (Pérez-Esteban et al., 2016).

The objective of the present study was to find out the arsenic sorption capacity of a tailored technosol composed of a ferralsol, with $25,531 \mathrm{mg} \mathrm{kg}^{-1}$ of Fe ( $2 \% w / w$, associated to Fe and Mn oxides) and multicomponent nanoparticles.

\section{METHODS}

Water samples were collected at three discharges of artesian gold-processing plants located in the border of the Amarillo River (Portovelo, Ecuador), the main collector of liquid wastes from the gold-processing artesian plants. $\mathrm{pH}, \mathrm{Eh}$, electric conductivity were measured on site and heavy metals and As were analyzed with an atomic absorption spectrometer using standardized methods. For the fabrication of multicomponent nanoparticles (MCNPs) $\mathrm{FeCl}_{3} \cdot 6 \mathrm{H}_{2} \mathrm{O}$ and $\mathrm{Na}_{2} \mathrm{SO}_{4}$ solutions were mixed and purged with nitrogen. Then, $\mathrm{NaBH}_{4}$ and orange peel extract were added as co-reductants. The technosol was prepared mixing $12.5 \mathrm{mg}$ of MCPNPs and 4,987.5 mg of soil. Arsenic sorption was performed in batch tests mixing $5 \mathrm{~g}$ of technosol with $100 \mathrm{~mL}$ of arsenic contaminated water at neutral $\mathrm{pH}$.

Mine drainage water was doped with six different concentrations of arsenic (25, 50, 100, 200, 400, $\left.600 \mu \mathrm{g} \mathrm{L}^{-1}\right)$. The amount of arsenic sorbed on the technosol was determined by mass balance using the equation (Vanderborght \& Van Grieken, 1977):

$\mathrm{q}=\mathrm{V} / \mathrm{m}\left(\mathrm{C}_{\mathrm{i}}-\mathrm{C}_{f}\right)$

where $\mathrm{q}=$ concentration of As in the soil, $\mathrm{V}=$ volume of water contaminated with As, $\mathrm{m}=$ mass of soil and $\mathrm{C}_{i}$ and $\mathrm{C}_{f}$ initial and final As concentrations. 
Table 1. Metal concentration in soil, used for preparing of technosol.

\begin{tabular}{|c|c|c|c|c|c|c|c|}
\hline $\begin{array}{l}\text { Soil } \\
\text { Fraction }\end{array}$ & $\begin{array}{l}\mathrm{Cu} \\
\mathrm{mg} \mathrm{kg}^{-1}\end{array}$ & $\mathrm{Cd}$ & $\mathrm{Zn}$ & $\mathrm{Cr}$ & $\mathrm{Pb}$ & $\mathrm{Fe}$ & As \\
\hline Exchangeable & 0.37 & 0.56 & 0.78 & 1.65 & 2.26 & 0.8 & 0.00 \\
\hline Sorbed-carbonate & 1.23 & 0.50 & 2.11 & 0.96 & 5.70 & 3.43 & 0.00 \\
\hline Oxidizable (Fe/Mn oxides) & 1.89 & 0.00 & 154.32 & 1.12 & 6.42 & 432.88 & 0.09 \\
\hline Reducible & 3.54 & 0.15 & 5.27 & 2.78 & 1.67 & 190.09 & 0.00 \\
\hline Residual & 4.5 & 0.00 & 6.94 & 0.75 & 3.21 & 24904 & 0.02 \\
\hline Total & 11.53 & 1.21 & 169.42 & 7.26 & 19.26 & 25521.24 & 0.11 \\
\hline
\end{tabular}

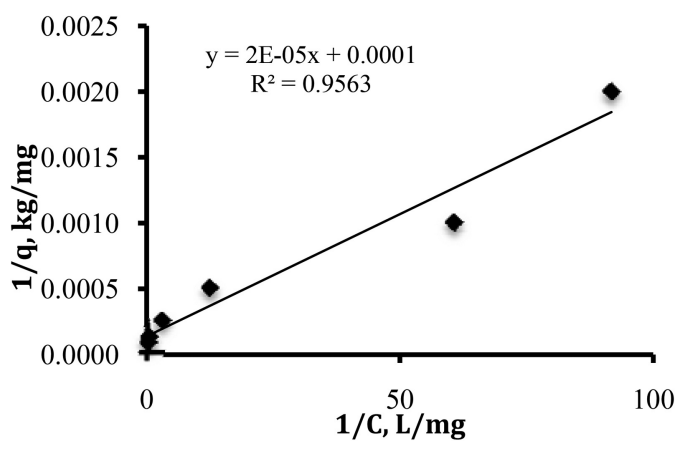

Figure 1. Sorption of arsenic on technosol.

\section{RESULTS AND DISCUSSION}

Water samples collected from the mine drainage had $\mathrm{pH}$ of 8.56 and $\mathrm{Eh}-107.50 \mathrm{mV}$. Under these conditions, arsenic is probably precipitating into the sediments basin. However, the variation of these parameters can easily lead to the release and mobilization of arsenic into the water (Polizzoto et al., 2006) what is evidenced by the variation of arsenic concentrations from 4.8, 8.6 and $27.5 \mu \mathrm{g} \mathrm{L}^{-1}$. Concentrations of metals in soil are given in Table 1. Soil with concentration of $25,531 \mathrm{mg}$ of total iron $\mathrm{kg}^{-1}\left(432.9 \mathrm{mg} \mathrm{kg}^{-1}\right.$ of Fe associated to oxides) was selected for preparing the technosol. The As-prepared MCNPs showed sizes in the range of 5 to $20 \mathrm{~nm}$ containing zero valent iron in the core and iron sulfide in the coverage similar to those reported by Cumbal et al. (2015). With the As-prepared technosol, we run adsorption tests for arsenic. In Figure 1, it is observed that experimental data fit very well the Langmuir isotherm model:

$\mathrm{q}=\left(\mathrm{Q}_{\max } \mathrm{b} \mathrm{C}\right) /(1+\mathrm{bC})$.

The maximum adsorption capacity and adsorption bond energy (Langmuir, 1918) $\left(\mathrm{Q}_{\max }\right)$ and $\mathrm{b}$ are $71,185 \mathrm{mg} \mathrm{kg}^{-1}$ and $7.50 \mathrm{~kg} \mathrm{mg}^{-1}$, respectively. The high sorption capacity of the technosol for arsenic could be associated to iron oxides (Cumbal, 2004) contained in soil and the zero valent iron and the iron sulfide of the nanoparticles (Cumbal et al., 2015).

\section{CONCLUSIONS}

Technosol prepared with iron-rich soil mixed with multicomponent nanoparticles shows a good sorption capacity for arsenic dissolved in the mine drainage water. Adsorption results fit very well a Langmuir isotherm. Approximately $95 \%$ of arsenic is captured from the aqueous phase contaminated with $4.5 \mathrm{mg} \mathrm{L}^{-1}$.

\section{REFERENCES}

Bolaños, D. 2015. Aplicación de Tecnosoles para la recuperación de suelos y aguas afectados por actividades de obras civiles, urbanas y minería. PhD Tesis, Universidad de Santiago de Compostela, Santiago de Compostela, Spain.

Cumbal, L. 2004. Polymer-supported hydrated iron oxide (HFO) nanoparticles: characterization and environmental applications. PhD Dissertation, Lehigh University, Bethlehem, PA, USA.

Cumbal, L., Debut, A., Delgado, D., Bastidas, C. \& Stael, C. 2015. Synthesis of multicomponent nanoparticles for immobilization of heavy metals in aqueous phase. NanoWorld J. 1(2): 105-111.

Langmuir, I. 1918. The adsorption of gases on plane surfaces of glass, mica and platinum. J. Am. Chem. Soc. 40(9): 1362-1403.

Macías, F., Caraballo, M.A., Rötting, T.S., Pérez-López, R., Nieto, J.M. \& Ayora, C. 2012. From highly polluted Znrich acid mine drainage to non-metallic waters: implementation of a multi-step alkaline passive treatment system to remediate metal pollution. Sci. Total Environ. 433(1): 323-330.

Pérez-Esteban, J., Caballero-Mejía, B., Masaguer, A. \& Moliner, A. 2016. Effect of magnetite nanoparticles on heavy metals behavior in contaminated soils. VII Congresso Ibérico das Ciências do Solo (CICS 2016), VI Congresso Nacional de Rega e Drenagem, pp. 419-422.

Polizzotto, M.L., Harvey, C.F., Li, G., Badruzzman, B., Ali, A., Newville, M., Sutton, S. \& Fendorf, S. 2006. Solid-phases and desorption processes of arsenic within Bangladesh sediments. Chem. Geol. 228(1-3): 97-111.

Vanderborght, M. \& Van Grieken, E. 1977. Enrichment of trace metals in water by adsorption on activated carbon. Anal. Chem. 49(2): 311-316. 
4.4 Arsenic solidification and immobilization for contaminated soils 


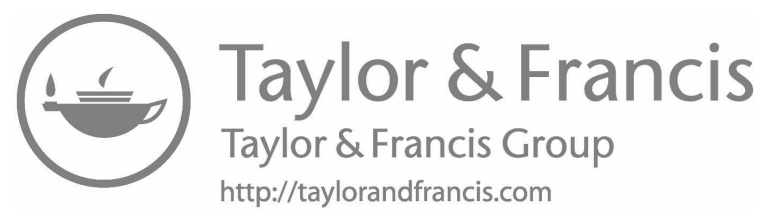

